\title{
Scenes from Provincial Life: Authenticity and Ethics of (Auto) Biographical Representation in J. M. Coetzee's Trilogy of Auto-fiction
}

\author{
Taşra Hayatından Manzaralar: J. M. Coetzee'nin Kurgusal Otobiyografi \\ Üçlemesinde Ö̈günlük Problemi ve (Oto)biyografik Temsilin Etiği
}

\begin{abstract}
Mehmet BÜYÜKTUNCAY*
Abstract: Contemporary life-writing, exercised within various cultural, political and ethnic backgrounds, have made questionable authenticity and referentiality in respect to the collapse of the monumental notion of the wholeness of the self. Likewise, in his trilogy of fictionalized autobiography, J. M. Coetzee indulged in homo-diegetic experiments based upon the transitivity between the autobiographical mode and fictional discourse. The alternation of conflictual identities and the fluctuating identity models in Boyhood (1997) and Youth (2002), which are third person narratives, underscores the auto-biographer's protean selves. The last in the trilogy, Summertime (2009), is in the form of a collaborative project of biography after Coetzee's fictitious death conducted by a fictitious biographer and five interviewees accounting for different segments of his life. This study aims to examine the interplay between the auto-biographer's multifarious subject positions and the multiplicity of discursive modes employed in Coetzee's trilogy. Subsequently, the ethics of representing the other will be evaluated from the perspective of representing the self-as-the-other. That Coetzee ends up being reduced to partial and provisional appearances in the life-stories of the others implies that his overall project targets a gradual self-diminishment, instead of reaching towards a gratifying portrait of self-realization.
\end{abstract}

Keywords: Authenticity, referentiality, self-representation, identity, self, other

Özet: Farklı kültürel, siyasal ve etnik bağlamlarda üretilen biçimleriyle çağdaş yaşam öyküsü yazını, benliğin somut ve yekpare bütünlüğü gibi muazzam bir düşüncenin çözülmesine binaen, özgünlük ve göndergesellik kavramlarını sorunlu hale getirmiştir. Kurgusal otobiyografi üçlemesinde J. M. Coetzee, benzer biçimde, otobiyografik anlatım ve kurgusal söylem arasındaki geçişkenlik imkânından hareketle benliğin temsiline dair anlatısal deneylere girişmektedir. Her ikisi de üçüncü tekil şahıs anlatısı olarak kaleme alınmış olan Boyhood [Çocukluk] (1997) ve Youth [Gençlik] (2002) adlı eserlerde sürekli dönüşen ve hatta çelişen kimlik modellerinin sırayla birbirini izlemesi otobiyografik öznenin benliğindeki değişken veçhelere vurgu yapar. Üçlemenin son eseri olan Summertime [Yaz Mevsimi] (2009), Coetzee'nin muhayyel ölümünün ardından kendisi de kurmaca olan bir biyografi yazarının Coetzee'nin hayatının farklı kesitlerine ait beş farklı kişi ile görüşmek suretiyle yürüttüğü ortak bir biyografi projesi biçiminde tasarlanmıştır. Bu çalışma Coetzee'nin üçlemesinde görülen otobiyografik öznenin muhtelif konumlarıyla çeşitli söylem biçimleri arasındaki karşılıklı etkileşimi incelemeyi hedeflemektedir. Bunu takiben, 'öteki’nin yazınsal temsilindeki etik boyut otobiyografik öznenin kendisini bir başkası olarak temsil etmesi açısından ele alınacaktır. Coetzee'nin başkalarının yaşam öykülerinde kısmi ve geçici tezahürleriyle resmedilme durumuna düşmesi üçlemenin genel projesi çerçevesinde tatminkâr bir kendini gerçekleştirme sürecinden ziyade öznenin bütünlüğünün aşama aşama seyrelerek yok olmasına işaret eder.

Anahtar Sözcükler: Özgünlük (aslına uygunluk), göndergesellik, öz-temsil, kimlik, benlik, öteki

\footnotetext{
* Ph.D., Celal Bayar University, School of Foreign Languages, Manisa, mehmet.buyuktuncay@gmail.com
} 


\section{Introduction}

Once the general task of writing autobiography is regarded as conveying the author's authentic self-experiences as truthfully as possible, the need to use different narrative or discursive modes in autobiography turns out to pose problematic blind spots as to the genuine aim of these discursive strategies. Why do auto-biographers prefer narratological figures, tropes or textual games if their true aim is merely to posit an unmediated access to their real-life experiences? Does the urge to evade typical linear narratives in the first person bear a claim to be a more realistic way of expression of private experiences? Or does it tacitly function to put forward the fact that no such claim is possible? If the unity of the self is once taken for granted, the authenticity of the auto-biographer's past life as he lived it seems to be concretely out there within his own reach. Yet, what if the task to remain authentic works against the wholeness of the self? In other words, does the use of textual devices to seep into various aspects of the autobiographer's past open fissures in the process of self-representation in an autobiographical narrative, which originally was meant to display the authentic self in its true context? These constitute the main category of questions that Coetzee's autobiographical trilogy revolves around. Together with his will to represent his various distant past selves, Coetzee's need to relate to 'the other' and others' perspectives pushes him to draw an overarching link between authenticity and the ethics of telling others' stories. The tension between these two poles is so high in his trilogy that the authentic self ends up dissolving into oblivion in the last piece of his autobiographical work through a gradual process of locating the self in relation to the various perspectives of others.

\section{Boyhood}

Boyhood is set in the town of Worcester, some 150 kilometres from Capetown. In this first book of the trilogy, Coetzee depicts himself in search for a sense of belonging to a community. The dominant tone for the representation of his boyhood is his failure, or rather hesitation, to identify with a definite group of people. Therefore, a succession of shifting identity models mark Coetzee's early experiences of his self, his neighbourhood, his family and his ethnic community. Since he regards himself and his family as strange and different from other kids and their families, he's depicted as inclined towards "identity vectors as multiply constructed," (Smith and Watson, 2001, 36) which occasionally keep conflicting with one another. First of all, he's a white Afrikaner, with an Afrikaans surname. He conceives himself unnatural since "[h]e comes from an unnatural and shameful family in which not only are children not beaten but older people are addressed by their first names and no one goes to church and shoes are worn every day" (Boyhood, 1998, 6). He even wishes his father to beat him to turn him into a normal boy.

At school, Coetzee has to put up with the bullying of boys from both Afrikaner and Catholic communities. The Catholic boys nag him and the Christians persecute him, Coetzee narrates, but the Jews do not judge. And since the Jews too wear shoes, he is comfortable with the Jews. However, as ruthless and untrustworthy Jews are the main characters of his uncles' and mother's stories, he cannot ally with them. Judging with his childish interpretation patterns, he decides to pretend that he's a Catholic although he has no familial or emotional tie with the creed. Yet, for one thing, his infantile imagination makes him think that secretly converting into Catholicism will keep him safe among other boys. In addition, just as he misconceives the heroic ideal of being a Roman that Catholicism evokes in him, he is content with his new religion:

Despite the real menaces of the real Catholics, despite the hovering possibility that the priest will visit his parents and unmask him, he is 
thankful for the inspiration that made him choose Rome. He is grateful to the church that shelters him; he has no regrets, does not wish to stop being a Catholic. If being a Christian means singing hymns and listening to sermons and then coming out to torment the Jews, he has no wish to be a Christian. The fault is not his if the Catholics of Worcester are Catholic without being Roman, if they know nothing about Horatius and his Comrades holding the bridge over the Tiber ('Tiber, Father Tiber, to whom we Romans pray'), about Leonidas and his Spartans holding the pass at Thermopylae, about Roland holding the pass against the Saracens. He can think of nothing more heroic than holding a pass, nothing nobler than giving up one's life to save other people, who will afterwards weep over one's corpse. That's what he would like to be: a hero. That is what proper Roman Catholicism should be about (Boyhood, 1998, 24-25).

Yet, Coetzee as an infant never ceases to set partial identifications with various other models, as he does with Roman Catholicism. For instance, he chooses Russians in 1947 when everyone else sides with the Americans against the threat of communism. He reads extensively about World War II, studies Russian weaponry as if they are toys and tries to learn everything about Russia including its geography, traditions and etc. It is upon his parents' serious disapproval that he realizes that "liking the Russians was not part of a game, it was not allowed" (Boyhood, 1998, 27).

Although Coetzee is of Afrikaner descent, he sympathizes with the English on many occasions:

...though his father is more Afrikaans than English, though he himself speaks Afrikaans without English accent, he could not pass for a moment as an Afrikaner. The range of Afrikaans he commands is thin and bodiless; there is a whole dense world of slang and allusion commanded by real Afrikaans boys to which he has no access (Boyhood, 1998, 124).

He is far too happy that he is not Afrikaans and doesn't have to speak that 'rude' language which sounds like the talk of a 'whipped slave'. However, there are also times when he obviously speaks out his mind by saying that Afrikaans is like a second skin for him; and it is also relief for him to be fashioned by the language into another person who is "simpler, gayer, lighter in his tread" and admits that it is like "a ghostly envelope that accompanies him everywhere" (Boyhood, 1998, 125). And that several phrases and sentences in Afrikaans are spread throughout the book is representative of this natural attitude.

He hates the Nationalists in power. He is also surprised at the fact that the Boer Wars are not covered in English-medium classes. As an Afrikaaner, Coetzee is supposed to side with the Boers fighting for freedom against the British rule. Though the British are the villains of the war, Coetzee thinks, with their arrogant and haughty generals, he dislikes the Boers for their long beards and ugly clothes and likes "the British for marching to their death to the skirl of their bagpipes" (Boyhood, 1998, 67). Very naively, he fails to understand why so many people fail to appreciate England since for him England means heroism as indicated by the names Dunkirk and the Battle of Britain, Sir Lancelot, Richard the Lionheart, Robin Hood and etc. Yet, he is also disappointed by the English for their contempt for the Afrikaans by deliberately mispronouncing Afrikaans words. At these times, he draws back from the English and insistently keeps on pronouncing the words as they should be pronounced with all the hard conso- 
nants and difficult vowels; and thus makes no concessions even among the English (Boyhood, 1998, 125).

Therefore, what Coetzee experiences in this first part of the trilogy is an identity split among various superficial role models and stereotypes. Too many identity vectors pull him apart in various directions at the same time, which is also apparent in the love-hate relationship established between him and his ethnic-religious background. So, in this first book, there is the challenge and the effort, in Smith and Watson's (2001) words, of "braiding of disparate voices" in the autobiographical subject "whose cultural origins and allegiances are multiple and conflicting" (145). The challenge is also at work, yet with different dynamics, in the second book of the trilogy, Youth, where Coetzee will have to test face to face his loyalty to everything that England stands for. And, he already knows that except for English, which he commands with ease, he will fail some of those tests upon his arrival in London.

As it can also be seen, in Coetzee's style of writing, the infantile judgements and interpretation patterns bear a childish perspective and they are distanced from the auto-biographer's present time of enunciation. The adult auto-biographer's mature consciousness seeing through the child's eye is at work in many instances and this is reminded to the reader in several cases. Then, how shall we interpret the case where Coetzee as an auto-biographer takes up distancing his past protean selves? The way that he narrates the experiences in his boyhood and fabulates the facets of his identity formation is by representing himself as an 'other'. This he achieves by representing the autobiographical figure in the third-person singular. Therefore, the true interpretation of Coetzee's distant selves lies in his use of the third-person.

The distancing of the narrator and the protagonist of the autobiography through the use of the third-person pronoun splits the unity of the subject and creates division between the perspectives of the speaker and the hero. As to this rift, Philippe Lejeune (1977) asserts in one of his seminal articles that third-person narratives reveal the schism in the multiple perspectives of the auto-biographer, which is implicit in the first-person narration (32). Therefore, autobiographical narration in the third-person also discloses the gaps and inconsistencies between the perspectives of the auto-biographer as a boy and as an old man. Hence, this distancing effect helps the reader strip bare the enforcement in conforming self-representation in rigid and particular identity frames. In the third person autobiographies, then, the protagonist of the narrated story becomes a distinct narrative figure. And consequently, according to Paul de Man (1979), this figured manner of narration makes more apparent the creation of a 'face' or 'prosopopeia' for the protagonist.

So, what is the impact of the use of figures in autobiographical narratives other than the discrepancy in perspectives or the duality of the narrative voice? Does the need to use a figure in the third-person also imply the ungraspable nature of authentic past selves, as in Coetzee's Boyhood? According to Heidi James Dunbar (2010), in parallel with Emmanuel Levinas's argument, the other lies at the limits of my power to grasp; and to know and speak for the other we are bound to position ourselves as the 'master' ("Authenticity and Textual," para. 4). Thus, just as this mastery of facts is violence for Dunbar so is the claim for authenticity a type of coercion. She notes: "So then, if authenticity is betrayal, and this betrayal is unavoidable simply because of the impossibility of faithfully rendering the multiple to a single unified narrative, from facts secreted about time and space; what then of authenticity?" (Dunbar, "Authenticity and Textual", para. 5). Especially when Coetzee's effort to speak of his self as an 'other' is considered, his deliberate task of undermining the claims of authenticity as the ultimate standard of autobiography can be better appreciated. Coetzee's games of focalization throughout the 
trilogy, especially in the third part, serves for the proposition that unmediated access to authentic past selves is an illusion. Therefore, in Coetzee's autobiography in the third-person, the indirectness of relating to oneself is frankly declared and the notion of identity as a relational construct is brought to the fore since the possibility of a disengaged self-knowledge is undermined by his preference for figured narration and transpositions in focalization.

This use of (third-person) figured narration accounted for so far is also the very narrative element that pushes Coetzee's autobiography one step closer to fiction. It is, firstly, because Coetzee constructs another perspective in the form of a figure other than his present self. Secondly, because we as readers may fail to keep in mind that the auto-biographer is the narrator that we forget what we are reading is an autobiography, not fiction. Lejeune (1977) warns the reader of third-person autobiographies to be mindful of the convention: "If the entire text is written in the third-person, there remains only the title (or a preface) to signal an autobiographical meaning. And if the text is long, the reader risks forgetting" (Lejeune, 1977, 38). Yet still, the overall system in Coetzee's Boyhood and Youth, both of which are written in the thirdperson, belongs to that of autobiography although there is a minor move towards fictional narration. The title of the book, extra-textual notes and the match between the auto-biographer's proper name on the book cover with that of the protagonist's in the story maintain the original autobiographical contract. Hence, we do not question the truth-value of what is told in Coetzee's autobiographies.

\section{Youth}

Likewise, in the second book, Youth, Coetzee's protagonist is amidst various directions and models, which also help him evolve into an artist. This book covers the period from Coetzee's age of 19 to 24 . Again, there are moments of identity crisis intersecting with sex, class and racial issues. However, the dominant convention here is that of 'bildungsroman' since it is mainly his search for artistic style, his transition from writing poetry to prose and his identification with different literary models and masters which have the major emphasis.

The geographical change of places, as Coetzee moves from Cape Town to London, in fact hints at a shift from rural values to urban lifestyle. After changing a couple of jobs, and eventually being settled in central London, Coetzee now experiences adaptation problems to the dominant culture and will see if he'll pass for a Londoner. He's a bit confused because "England is the home of two nations: he will have to choose between them, choose whether to be middle-class English or working-class English" (Youth, 2003, 103). However, it is Coetzee's white skin and his Moss Brothers suit, which he calls his 'protective coloration' representing his white, middle class status that keeps him away from the feeling of an unwelcome foreigner. Yet still, he believes that it is not a safe time to be a South African in England because South Africa has declared itself a republic and is expelled from the British Commonwealth (Youth, 2003, 86). In addition, his idea of the British fitting into a heroic ideal also gets weaker by the time he develops some political awareness. He still cannot conceive what the British have against the Russians though the Russians have never threatened to invade Britain. Furthermore, nor can he understand why the British side with the Americans, "who behave like bullies in Europe as all over the world?" (Youth, 2003, 84). In a broader sense, Coetzee summarizes his loss of a sense of belonging, resulting from a change of location, as follows: "He belongs to two worlds tightly sealed from each other. In the world of South Africa, he is no more than a ghost, a wisp of smoke fast dwindling away... As for London, he is as good as unknown here" (Youth, 2003, 131).

In his early youth, Coetzee thinks he essentially lacks "some definition of feature" (Youth, 2003 , 3). He gradually seeks for a more definite locus of identity in his pursuit of literary 
models. And in this pursuit both his loyalty to primary role models begin to change and he wakes up into a gallery of conflicting models, which eventually teach him to devise his own personal interpretation of the meaning of the world and the function of art. He has begun to prefer Pope to Shakespeare. He cannot comprehend how he could once have been so infatuated with Keats and the naïve sentiments the Romantics conveyed. He sees himself as a disciple of Ezra Pound. For him, "Pound and Eliot are trying to revitalize Anglo-American poetry by bringing back to it the astringency of the French" (Youth, 2003, 21). Pound and Eliot also commanded his selection of what to read from the nineteenth century poets and novelists. He also appreciates Wallace Stevens, Kafka, Ford Maddox Ford and later on Samuel Beckett. He never sympathizes with the extravagance and the obsession with madness that the Romantics had. However, he will substitute this extravagance in the Romantic notion of madness with his own concept of misery, which is almost an asset for his creativity:

Misery is his element. He is at home in misery like a fish in water. . . Happiness, he tells himself, teaches one nothing. Misery, on the other hand, steels one for the future. Misery is a school for the soul. From the waters of misery one emerges on the far bank purified, strong, ready to take up again the challenges of a life of art (Youth, 2003, 65).

Therefore, he drifts from one extreme to the other. Just as in Boyhood, in Youth too, the narrator makes these comments on his past self over a distance from within his mature state of consciousness, evoking a sense of naïveté as to his past pursuit of artistic identity and originality.

Nevertheless, in his oscillation among various poles, he also develops a sense of personal ethics which inclines towards an aesthetic of malevolence. Near the end of this second book there comes a confession-like statement which also undercuts his attitude against naïve authenticity in the manner of sticking to the true and real:

He does not need to think overlong to know what the right thing is. He could, if he chose, do the right thing with near infallible accuracy. What gives him the pause is the question of whether he can go on being a poet while doing the right thing. . The right thing is boring. So he is at an impasse: he would rather be bad than boring, has no respect for a person who would rather be bad than boring, and no respect either for the cleverness of being able to put his dilemma into words (Youth 165).

In reflection of this personal account of artistic attitude, there is another significant passage in the early pages of the book where Coetzee conveys his ideas about keeping a diary, which should also be taken as a key to his autobiographical maxim and understanding of authenticity in life-writing:

The question of what should be permitted to go into his diary and what kept forever shrouded goes to the heart of all his writing. If he is to censor himself from expressing ignoble emotions - resentment at having his flat invaded, or shame at his own failures as a lover - how will those emotions ever be transfigured into poetry? . . Besides who is to say that the feelings he writes in his diary are his true feelings? Who is to say that at each moment while the pen moves he is truly himself? At one moment he might truly be himself, at another he might simply be making things up. How can he know for sure? Why should he even want to know for sure? (Youth, 2003, 9-10). 
What is to be underlined here is that the self of the subject is prone to change in time, even at the very time of self-expression. The fashioning of the self in an autobiographical narrative either takes place through the transformative effect of narrative tropes or occurs against the multiplicity of the self by fixing it into a rigid frame of reference exclusive of all other alternatives of self-configuration. Thus, Coetzee's focus on the constant change in the nature of the autobiographical subject indicates that there is no metaphysical guarantee for the authenticity and narrative identity of the self.

\section{Summertime}

While in the first two books Coetzee aims to create a distance between the narrator and the hero via third-person narration, he goes much further to prove the maxim that authenticity is coercion in the third book, Summertime. It is an autobiography, or more of an autobiographical fiction, in the form of a collaborative biography. This last piece is a limit case in autobiographical practice where Coetzee violates the basic autobiographical convention: Here, the autobiographical narrator, J. M. Coetzee, is dead. Coetzee's fictitious biographer, Mr. Vincent, is running a project of writing Coetzee's biography, by interviewing five people from different crosssections of Coetzee's life: Julia, Margot, Adriana, Martin and Sophie. All the interviews take place at different locations and times. Furthermore, it is also disclosed that the interviews do not appear in the order they were given. Besides, Summertime is a composite of various distinct modes of writing including notebooks, biographer's notes, interviews and letters. Mr Vincent sends Cotzee's notebooks and related letters to his interlocutors before each interview and requires the interviewee to think about the content of what Coetzee wrote. Thus, the interviewees have the right to assess their own opinions and versions of what is accounted in Coetzee's notes. Extracts from Coetzee's notebooks bear an overtly political overtone. In addition, though diurnal mode of writing scribbled by Coetzee in his notes and letters seem to create a claim of authenticity, they are paradoxically and deliberately separated from the interview sections, whose main function is to lay bare the dissolution of authenticity in narrating others' lives. Thus, by making himself totally vanish in his autobiography and yielding himself to his fictitious biographer and his biography project, Coetzee problematizes the ethics of writing biography, which, in the end, cross-cuts the problem of authenticity in autobiography.

The common task behind each interview is to display how Coetzee's personal accounts of his private experience seem from the outside through the perception of the 'other'. How these experiences are narrated and narrativized is also the other face of the matter. The focalization, contrary to Boyhood and Youth, is limited to the perspectives of the interviewees. However, there is always a certain extent of tension between the interviewees' perspectives and that of the biographer. The rift between what each interviewee tells of Coetzee and the story Mr. Vincent would like to hear points at the discursive nature of constructing someone's life story. Thus, in each interview there are disagreements as to what the interviewee means and how it is structured by Mr. Vincent into a biographical text. For instance, Julia tells the story of how she cheated on her husband with Coetzee as her secret lover. Yet, she strictly warns Mr. Vincent against fashioning her remarks as the story of a woman in Coetzee's life among many. Julia cooperates with the biographer and accepts to tell Coetze's story as it covered a portion of her life; yet she also expresses that she cannot just isolate Coetzee's life-story out of her own. Thus, she deliberately tells excessively of herself more than of Coetzee, and paradoxically ends up displacing Coetzee from being the major figure in his biography.

In another interview, Mr. Vincent tells Margot that he has pulled his written questions off from their previous interview and inserts Margot's answers into the biography as one ceaseless 
narrative of Margot's on Coetzee. Thus, Margot's comments on Coetzee's authentic past experiences are twice distanced from their origin. In this new form of narrative, Margot is also seen to be narrating in the-third person. Moreover, Mr. Vincent goes on with his daring experiments with Margot's interview. He writes fictitious letters from Margot to Coetzee and vice versa depending on what he learned from Margot about their relationship. There definitely is a transposition of discourse from biography to fiction, which surfaces as Mr. Vincent and Margot go over the re-written text. Although Margot occasionally asks of Vincent to delete some details which don't seem to reflect the truth as she told it beforehand, there still remains the greater problem of the loss of Margot's control on what she originally told the biographer. Though Mr. Vincent is determined to change just the form, but not the content of Margot's interview, and though he constantly asks for permission to keep or omit her remarks in the text, Margot is still not satisfied with the shift of focus and meaning upon Mr. Vincent's adjustment of the form. And she becomes really doubtful about the termination of authenticity and referentiality which comes through the change of discourse.

Similar questions as to referentiality and authenticity also appear in the following interviews. In her interview, which takes place by the help of a translator, Adriana shows discontent with Mr. Vincent's overall perspective which misjudges her relationship to Coetzee. She does not let him use her photographs in his project. And the critical question is about whether a biography is written so as to justify a particular image of a person, as it is perceived by the biographer. Mr. Vincent also admits to Martin that he, as a biographer, has to set a balance between the narrative and the point of view, which is the very spot where the biographer's intervention takes place into the real life experiences of the subject of biography. In the same way, Sophie wonders if Mr. Vincent regards her story as more real than what Coetzee tells of himself. And another critical question follows: Which one does the biographer prefer as a more appropriate resource for his work: a unified self-narration from his subject's pen or various cross-sections from his subject's life as accounted by different people, which he can adjust as he wishes? Is a biography a fiction among other possible fictions?

All these questions pertaining to the ethics of relating to another's life and how biography works, in fact, concentrate on the authenticity of self-representation in Coetzee's highly experimental auto-fiction. Coetzee reveals the mechanism of textual coercion by bringing forward the process of fictionalizing real-life data and developing it into one's life story. Therefore, Coetzee plays with the conventions of autobiography and fiction by emphasising and manipulating the transitivity between them; and thus he highlights the gradual diminishing of authenticity within figured narration.

\section{Conclusion}

In an article he wrote on the confessional mode of life-writing in Tolstoy, Rousseau and Dostoyevsky, Coetzee himself inquires if a secular confession about the truth of the self is possible without self-deception. With reference to Jean Starobinksi, Coetzee (1985) mentions a move from 'truthfulness' to 'authenticity'. He writes: "Authenticity does not demand that language reproduce a reality; instead it demands that language manifests its 'own' truth" (Coetzee, 1985, 209). In the same manner, in Summertime, with his absent presence and discursive experiments, Coetzee creates linguistic authenticity in contrast to referential authenticity. When his overall task in his trilogy is considered, he is deliberately indulged in diminishing the autobiographical figure into non-existence just like the displacement of the selfnarrating voice into nothingness in Samuel Beckett's novels. When an auto-biographer tries to call up a figure, or a personification, to represent his past self, he indirectly displaces or 
disfigures his authentic self since "all knowledge, including self-knowledge, depends on figurative language or tropes" (Anderson, 2001, 13). According to Paul de Man (1979), just because autobiography thus produces fictions or figures instead of authentic self-knowledge, it also "veils a defacement of the mind of which it is itself the cause" (930). Thus, Coetzee's procedures of experimentation with creating figures or faces for his self and then eventually sending them to oblivion is a manifestation of his deliberate effort to undermine the notion of authentic self-knowledge in traditional autobiography writing. Finally, in his experimental autobiographical form, Coetzee achieves a combination of Rousseau, the nineteenth century Russian novelists and Samuel Beckett respectively due to the employment of fictive dialogues attributed to real characters, the tendency for a secular mode of confession and the move towards decentralization of the self-narrating voice.

\section{Author's Note}

This study was presented at the $11^{\text {th }}$ Biannual Conference of the European Society for the Study of English (ESSE) in September 2012 at Bogazici University, Istanbul, Turkey.

\section{REFERENCES}

Anderson, L. (2001). Autobiography. London: Routledge.

Coetzee, J. M. (Summer 1985). "Confession and the Double Thoughts: Tolstoy, Rousseau, Dostoevsky". Comparative Literature, 34 (3), 193-232. Retrieved from: http://www.jstor.org/stable/1771079

Coetzee, J. M. (1998). Boyhood: Scenes from Provincial Life. New York: Penguin.

Coetzee, J. M. (2011). Taşra Hayatından Manzaralar. İstanbul: Can Yayınları.

Coetzee, J. M. (2003). Youth. London: Vintage.

de Man, P. (December 1979). "Autobiography as Defacement”. Comparative Literature, 94 (5), 919-930. Retrieved from: http://www.jstor.org/stable/2906560

James-Dunbar, H. (2010, April 6). "Authenticity and Textual Violence: the Case for Autofiction". Retrieved from: http://www.opendemocracy.net/heidi-james-dunbar/authenticity-and-textual-violencecase-for-autofiction

Lejeune, P. (Autumn 1977). "Autobiography in the Third Person”. New Literary History, 9 (1), 27-50. Retrieved from: http://www.jstor.org/stable/468435

Smith, S., \& Watson, J. (2001). Reading Autobiography: A Guide for Interpreting Life Narratives. Minneapolis: University of Minnesota Press. 